Volume 4 Nomor 2, Juli-Desember 2020: hlm. 157-170.

Fakultas Hukum, Universitas Lampung,

Bandar Lampung, Lampung, Indonesia.

E-ISSN: 2598-3105 P-ISSN: 2723-2581

http://jurnal.fh.unila.ac.id/index.php/cepalo

\title{
PROBLEMATIKA WASIAT WAJIBAH TERHADAP AHLI WARIS BEDA AGAMA DI INDONESIA
}

\section{PROBLEMATIC OF WAJIBAH TESTAMENT OF DIFFERENT RELIGIOUS HEIR IN INDONESIA}

\author{
Dwi Andayani1 ${ }^{1}$, Tetty Hariyati ${ }^{2}$ \\ ${ }^{1}$ Universitas Pakuan, Email: dwi.andayani@unpak.ac.id \\ ${ }^{2}$ Universitas Tarumanagara, Email: tettyhariyati.info@gmail.com
}

Submitted: July 24, 2020; Reviewed: August 15, 2020; Accepted: August 31, 2020

DOI: 10.25041/cepalo.v4no2.1893

\begin{abstract}
Abstrak
Permasalahan terkait pengaturan hukum yang sulit diatur oleh hakim adalah terkait permasalahan waris beda agama dengan sumber hukum Islam yang berlaku dan bagaimana penerapannya dalam kehidupan masyarakat. Dalam pengaturan secara sempit diatur dalam pasal 209 kompilasi hukum Islam tahun 1991. Selain itu fakta bahwa waris Islam yang mengacu pada sumber hukum Islam adalah Alquran dan Hadis yang kini telah dirangkum dalam Keputusan Presiden Penyusunan Hukum Islam Nomor 1 tahun 1991. Jenis penelitian yang digunakan adalah jenis penelitian normative dengan analisis terhadap peraturan perundangan-undangan yang berlaku terkait masalah hukum yang dibahas. Hasil penelitian menunjukkan bahwa hakim agung dalam memutus perkara waris beda agama ini lebih mempertimbangkan aspek keadilan sosial dan kemaslahatannya. Walaupun hal ini sebenarnya bertentangan dengan sumber Hukum Islam baik dalam Al-Qur'an maupun Hadits.
\end{abstract}

Kata Kunci: Ijtihad, Waris, Wasiat Wajibah.

\section{Abstract}

Problematics of the application of the law of unruly by the judges on the inheritance of different religions is associated with the prevailing source of Islamic law and how its application in the life of society. In a narrow setting the will of the face is governed in article 209 of the compilation of Islamic law year 1991. Because the fact on the inheritance of Islam is patting the source of Islamic law is the Qur'an and Hadith, which has now been summarized in the presidential decree of the compilation of Islamic law No. 1 year 1991. Type of research used normative type of study is normative research. It is the research and analysis on the prevailing law regulations with associated legal issues. The results of research showed that the Supreme Court decision judge in of inheritance different religions was more concerned with aspects of social justice and benefits. Although, it is actually contrary to the source of Islamic law both in the Al-Qur'an and Hadith. 
Keywords: Ijtihad, Inheritance, Wajibah Testament.

\section{A. Pendahuluan}

Pancasila merupakan dasar pada hukum agama dalam politik hukum Indonesia yang menjadi landasan dalam perkembangan kehidupan beragama masyarakat Indonesia. ${ }^{1}$ Berkedudukan sebagai falsafah bernegara Indonesia, Pancasila memiliki arti penting serta kedudukan sentral dalam membangun budaya bangsa yang beradab dan memiliki rakyat dengan karakteristik yang religius. Terbangun sebagai negara yang memiliki latarbelakang yang beranekaragam dan sangat majemuk membuat komposisi hukum yang terbangun juga beragam pula. Komposisi dari agama yang ada di Indonesia terdiri atas enam agama besar, terdapat agama islam, Protestan/Kristen, Katolik, Hindu, Buddha dan Khonghucu.

Dominasi islam di Negara Indonesia mencapai sampai 87,2\% (delapan puluh tujuh koma dua persen) dengan jumlah mencapai 207 (dua ratus tujuh) juta orang. Kedua, agama protestan yang memiliki presentase hingga 6,9\% (enam koma sembilan persen) dengan penduduk berjumlah 1517 (Seribu limaratus tujuh belas) orang; ketika, agama katolik yang muncul pertamakali di kepulauan maluku karena bangsa portugis pada saat itu; keempat, agama hindu yang memiliki penganut $1,7 \%$ dari populasi rakyat Indonesia secara menyeluruh. Selanjutnya ialah agama buddha yang memiliki jumlah presentase $0,7 \%$ dari rakyat Indonesia, dan teakhir ialah agama khonghucu yang terakhir diakui di Indonesia pada masa presiden Gus Dur.

Komposisi dari jumlah agama konghucu ialah $0,05 \%$ dari jumlah keseluruhan rakyat. $^{2}$ Terlihat dari data tersebut memperlihatkan secara jelas, bahwa terdapat agama yang sangat menjadi mayoritas di Indonesia. Islam menjadi agama yang amat menjadi mayoritas dengan jumlahnya yang lebih dari 207 juta manusia. Maka dari itu tidak heran jika banyak permasalahan hukum yang timbul dan berhubungan dengan agama tersebut. Terlihat bahwa dominasi orang yang beragama islam sangat banyak di Indonesia, salah satu sumber hukum Indonesia adalah hukum Islam selain hukum barat dan hukum adat. Negara yang memiliki warga negara yang sangat beraneka ragam perlu didukung dengan sistem hukum yang bisa mewakilkan seluruh kepentingan rakyat.

Hukum Islam sendiri memiliki landasan hukum dalam menjalankan seluruh kegiatan agamanya, dasar hukum tertinggi dari agama islam adalah Al-Qur'an dan Al-Hadits. ${ }^{3}$ AlQur'an merupakan kitab suci yang berisi petunjuk bagi umat islam, ${ }^{4}$ sedangkan Al-Hadits adalah sikap dan ucapan nabi dalam agama islam. ${ }^{5}$ Hukum Islam sendiri memiliki kedudukan dalam sistem hukum Indonesia melalui pengakuan yuridis yang termuat dalam peraturan perundang-undangan. ${ }^{6}$ Eksistensi hukum Islam dalam masyarakat Indonesia dapat terlihat dari kesadaran masyarakat tentang hukum dan keadilan yang tidak terpisahkan dalam kerangka

\footnotetext{
${ }^{1}$ Amran Suadi, Mardi Candra, Politik Hukum Perspektif Hukum Perdata dan Pidana Islam serta Ekonomi Syariah (Jakarta: Kencana, 2016), 4

${ }^{2}$ https://news.detik.com/berita/d-4904472/6-agama-di-indonesia-kitab-suci-dan-hari-besarnya, diakses pada 01 October 2020.

${ }^{3}$ Eva Iryani, "HUKUM ISLAM, DEMOKRASI DAN HAK ASASI MANUSIA," Jurnal Ilmiah Universitas Batanghari Jambi 17, no. 2 (2017): 24-31, 25, DOI: 10.33087/JIUBJ.V17I2.357.

${ }^{4}$ Muhammad Roihan Daulay, "STUDI PENDEKATAN ALQURAN," Thariqah Ilmiah 1, no. 01 (2014): 31-45, 31.

5 Agusman Damanik, "URGENSI STUDI HADIS DI UIN SUMATERA UTARA," SHAHIH (Jurnal Kewahyuan Islam) 1, no. 1 (2018): 83-94, 84, DOI: 10.30821/SHAHIH.V1I1.1886.

${ }^{6}$ Sumarni Sumarni, "KEDUDUKAN HUKUM ISLAM DALAM NEGARA REPUBLIK INDONESIA," $A L$ 'ADALAH 10, no. 2 (2012): 447-458, 456, DOI: 10.24042/ADALAH.V10I2.298.
} 
hukum nasional. Kemudian terdapat berbagai ketentuan hukum dan perundang-undangan Indonesia yang memuat materi hukum Islam. ${ }^{7}$

Eksistensi hukum islam di Indonesia diakui dalam konstitusi Indonesia yakni Pasal 29 ayat (1) Undang-Undang Dasar 1945 yang menyatakan bahwa "negera Indonesia berdasarkan atas Ketuhanan Yang Maha Esa". ${ }^{8}$ Selain itu, hukum islam secara khusus ditetapkan dalam Undang-Undang Nomor 7 Tahun 1989 tentang Peradilan Agama. ${ }^{9}$ Kemudian disusul dengan usaha-usaha menyusun Kompilasi Hukum Islam dan oleh Presiden Soeharto menginstruksikan kepada Menteri Agama untuk penyebarluasan sebagaimana tersebut dalam Inpres Nomor 1 Tahun 1991 tanggal 10 Juni 1991 yang disebut dengan Kompilasi Hukum Islam. ${ }^{10}$ Kompilasi Hukum Islam atau KHI adalah sekumpulan materi Islam yang ditulis Pasal demi Pasal, berjumlah 229 Pasal. ${ }^{11}$ Hanya Agama Islam yang menggunakan KHI sebagai panduan dalam menjalankan ketentuan-ketentuan yang diatur di dalam hukumnya. Daya ikat KHI pula hanya mengikat bagi orang yang mempercayai dan meyakini keyakinan agama Islam, tidak untuk orang dan warga negara yang menganut kepercayaan agama lain.

Salah satu masalah yang sering timbul dikehidupan masyarakat adalah masalah warisan. Kemudian dalam menangani permasalahan waris ini, hakim dapat memiliki kewenangan untuk melakukan penemuan hukum rechtvinding. Hal ini sebagaimana yang diatur dalam Pasal 5 Undang-Undang Nomor 48 Tahun 2009 tentang Kekuasaan Kehakiman. ${ }^{12}$ Selain itu, berdasarkan Pasal 229 Kompilasi Hukum Islam, hakim memiliki kewenangan penyelesaian suatu perkara yang berlandaskan pada rasa keadilan dan nilai-nilai di kehidupan masyarakat. ${ }^{13}$ Pada dasarnya hakim dapat ber-ijtihad dalam menyelesaikan suatu perkara menurut hukum islam. ${ }^{14}$ Ketika terdapat permasalahan yang tidak ada penjelasannya dalam Al-Qur'an dan AlHadits, maka para ulama Islam melakukan ijtihad untuk mencapai suatu kesepakatan dengan berpedoman pada Al-Qur'an dan Al-Hadits. ${ }^{15}$

Misalnya kewarisan non-muslim yang dikaitkan dengan wasiat wajibah. Mengenai keberadaan dari wasiat ini, Ulama Fiq'h mendefinisikan bahwa wasiat dengan artian sebagai penyerahan atau mendermakan harta secara sukarela dari seseorang kepada pihak lain yang

\footnotetext{
${ }^{7}$ Ruwainta Samniah, Akhmad Khisni, "KEDUDUKAN DAN KONTRIBUSI HUKUM ISLAM TERHADAP HUKUM NASIONAL DALAM BIDANG MU'AMALAT,” Jurnal Hukum Khaira Ummah 12, no. 3 (2017): 671-676, 673.

${ }^{8}$ Mohammad Daud, "KEDUDUKAN HUKUM ISLAM DALAM SISTEM HUKUM INDONESIA," Jurnal Hukum \& Pembangunan 12, no. 2 (1982): 267-287, 269, DOI: 10.21143/jhp.vol12.no2.898.

${ }^{9}$ Basri Basri, "PERKEMBANGAN PERADILAN AGAMA PASCA LAHIRNYA UU NOMOR 7 TAHUN 1989 HINGGA SAAT INI (KEWENANGAN, PEMBINAAN, PENGAWASAN DAN DASAR HUKUM)," TAHKIM 13, no. 2 ( 2018): 31-46, 31, DOI: 10.33477/THK.V13I2.366.

${ }^{10}$ Barmawi Mukri, "KEDUDUKAN DAN PERANAN KOMPILASI HUKUM ISLAM DALAM SISTEM HUKUM NASION AL,” Jurnal Hukum IUS QUIA IUSTUM 8, no. 17 (2016): 22-29, 27.

${ }^{11}$ Dadang Hermawan, Sumardjo, "KOMPILASI HUKUM ISLAM SEBAGAI HUKUM MATERIIL PADA PERADILAN AGAMA", Yudisia 6, no. 1, (2015): 24-46, 27.

12 Muhamad Kholid, "KEWENANGAN PENGADILAN NEGERI DAN LEMBAGA ARBITRASE DALAM PENYELESAIAN SENGKETA BISNIS,” ADLIYA: Jurnal Hukum Dan Kemanusiaan 9, no. 1 (2015): 168-184, 175, DOI: 10.15575/ADLIYA.V9I1.6162.

13 Nikmatun Nuzula, "PEMBAGIAN HARTA BERSAMA AKIBAT PERCERAIAN DI PENGADILAN AGAMA KEDIRI," Mahakim: Journal of Islamic Family Law 1, no. 1 (2017): 27-37, 34, DOI: 10.30762/mh.v1i1.1009.

${ }^{14}$ Destri Budi Nugraheni, Haniah Ilhami, Yulkarnain Harahab, "PENGATURAN DAN IMPLEMENTASI WASIAT WAJIBAH DI INDONESIA," Mimbar Hukum 22, no. 2 (2010): 311-329, 320, DOI: 10.22146/jmh. 16229.

${ }^{15}$ Abd. Salam Arief, "IJTIHAD DAN DINAMIKA HUKUM ISLAM," IN RIGHT: Jurnal Agama Dan Hak Azazi Manusia 7, no. 1 (2017): 1-14, 10.
} 
berlaku setelah orang tersebut wafat. ${ }^{16}$ Kemudian problematika yang menjadi titik perdebatan menarik dimasyarakat adalah mengenai jenis wasiat wajibah untuk ahli waris beda agama. Hukum yang akan digunakan dalam menegakkan dan menyelesaikan permasalan ini perlu diperjelas di dalam tulisan ini. Terdapat daya ikat hukum islam yang tidak bisa mengikat orang yang memiliki kepercayaan yang berbeda. Tetapi secara fakta dan data lapangan, kejadian ini ada dan menjadi suatu fenomena hukum. Hal-hal seperti ini sering terjadi di ranah praktek. Terdapat gap dan jurang pemisah antara konsep/teori dan praktek dilapangan.

Berdasarkan latar diatas, akan ditinjau lebih jauh terkait dasar seorang pertimbangan seorang hakim memutus perkara harta waris beda agama dengan wasiat wajibah, lalu sejauh mana wasiat wajibah ini bisa dipergunakan sebagai dasar pembagian harta waris beda agama. Penelitian ini dilakukan dengan Metode penelitian normatif. Penelitian normatif adalah penelitian mengakaji dan menganalisis mengenai peraturan perundangan-undangan yang berlaku dengan dikaitkan dengan isu hukum yang akan dibahas dalam artikel ini. ${ }^{17}$ Pendekatan perundang-undangan (Statute approach) dengan menelaah semua peraturan yang terakit dengan isu hukum. Selain pendekatan perundang-undangan terdapat pendekatan kasus (Case Approach), kegunaan pendekatan kasus dalam permasalahan ini ialah untuk melihat adanya fakta lapangan yang konkrit berkaitan dengan permasalahan yang akan ditulis serta bisa menentukan langkah dan solusi yang benar-benar menyelesaikan permasalahan secara nyata.

Menjadi penting adanya pendekatan dari pendekatan perundang-undangan didalam penulisan ini. Menelah secara sistematis dan komprehensif mengenai telaah aturan yang berkaitan dengan permasalahan pada tulisan ini. Peran konsep penafsiran hukum yang dilakukan oleh hakim sangat bermanfaat untuk melihat adanya kesesuain antara konsep dan praktek penerapan hukum tersebut.

\section{B. Pembahasan}

\section{Tatanan Konstruksi Hukum Islam}

Definisi dari hukum Islam atau syariat islam ialah sebuah sistem hukum dengan kaidahkaidah yang didasarkan pada firman Allah SWT dan Sunnah Rasul mengenai tingkah laku mukallaf (orang yang sudah dapat dibebani kewajiban) yang diakui dan diyakini, yang hukum tersebut memiliki kekuatan mengikat bagi setiap pemeluknya. Mengacu berdasarkan pada apa yang telah dilaksanakan oleh Rasul untuk melaksanakannya secara menyeluruh. Syariat menurut aspek gramatikal memiliki makna yaitu berarti hukum-hukum yang diperintahkan Allah Swt untuk pengikutnya yang disampaikan oleh seorang Nabi, baik yang memiliki koleras dengan kepercayaan (aqidah) ataupun yang berhubungan dengan amaliyah. Syariat Islam menurut penafsiran secara bahasa memiliki makna jalan yang dilalui umat manusia untuk menuju kepada Allah Ta'ala, ternyata agama islam tidak hanya sebuah agama yang memberikan ilmu tentang bagaimana mengimplementasikan ibadah kepada Tuhannya saja. ${ }^{18}$

Eksistensi dari sebuah aturan atau sistem yang langsung bersumber dari Allah SWT, menunjukan bahwa untuk mengkonstruksikan adanya relasi antara manusia dengan Allah Ta'ala dan hubungan manusia dengan sesamanya. Ajaran Islam menjadi sumber dari semua aturan tersebut. Sumber dari agama islam bernama Al-Quran dan Hadists. Maka dari itu

\footnotetext{
${ }^{16}$ Zaiyad Zubaidi, Muhammad Yanis, "IMPLEMENTASI WASIAT BERUPA 'HONORARIUM' MENURUT PANDANGAN WAHBAH ZUHAILI," Media Syari'ah 20, no. 2 (2020): 182-200, 186, DOI: 10.22373/jms.v20i2.6514.

${ }^{17}$ Risa Mahdewi, Desia Rakhma Banjarani, "FOOD SAFETY OF GENETICALLY MODIFIED ORGANISM ACCORDING TO INTERNATIONAL LAW AND ITS IMPLEMENTATION IN INDONESIA," Lampung Journal of International Law 2, no. 1 (2020): 35-46, 37, DOI: 10.25041/lajil.v2i1.2031.

${ }^{18}$ Eve Iryani, Op.Cit., 24.
} 
pemberian definisi hukum Islam adalah syariat yang berarti hukum yang dibentuk dan dibuat oleh Allah untuk umat-Nya yang dibawa oleh seorang Nabi SAW, berkaitan dengan aturan tersebut, ajaran agama yang berhubungan dengan kepercayaan (aqidah) maupun hukumhukum yang memuat adanya pengaturan dengan amaliyah (perbuatan) yang dilaksanakan oleh umat Islam secara menyeluruh. ${ }^{19}$

Sumber Hukum-Hukum Islam Hukum Islam bukan hanya sebuah teori saja namun adalah sebuah aturan-aturan untuk diterapkan di dalam sendi kehidupan manusia. Karena banyak ditemui permasalahan-permasalahan, umumnya dalam bidang agama yang sering kali membuat pemikiran umat Muslim yang cenderung kepada perbedaan. Untuk itulah diperlukan sumber hukum Islam sebagai solusinya, yaitu sebagai berikut: ${ }^{20}$

a. Al-Quran merupakan sumber hukum Islam tertinggi yang mempunyai legitimasi yang sangat kuat, Al-Quran, merupakan kitab suci umat Muslim yang diamanahkan kepada nabi terakhir, yaitu Nabi Muhammad SAW melalui perantara Malaikat yang bernama Jibril. Al-Quran berisikan kandungan-kandungan yang berisi perintah, larangan, anjuran, kisah Islam, ketentuan, hikmah dan sebagainya. Al-Quran menjabarkan secara spesifik bagaimana seharusnya manusia melaksanakan kehidupannya agar terbentuknya masyarakat yang memiliki akhlak mulia. Maka dari itulah, isi muatan dari ayat ayat AlQuran menjadi dasar yang utama untuk menetapkan suatu syariat dan ketentuan agama.

b. Al-Hadist merupakan sumber hukum Islam yang kedua, makna dan definisi dari Al-Hadist merupakan segala hal yang berlandaskan pada Rasulullah SAW. Bentuk-bentuk dari hal tersebut berupa perkataan, perilaku, diamnya beliau. Al-Hadist berisikan mengenai sebuah aturan-aturan yang merinci segala aturan yang masih global dalam Alquran. Kata hadits yang mengalami perluasan makna sehingga disinonimkan dengan sunnah, maka dapat berarti segala perkataan (sabda), perbuatan, ketetapan maupun persetujuan dari Rasulullah SAW yang dijadikan ketetapan ataupun hukum Islam.

c. Ijma' merupakan salah satu sumber hukum islam. Ijma bermakna dan memiliki arti adalah sebuah kesepakatan seluruh ulama mujtahid pada satu waktu setelah zaman Rasulullah atas sebuah perkara dalam agama. Ijma' yang dapat dipertanggung jawabkan adalah yang ada di zaman sahabat, tabiin (setelah sahabat), dan tabi'ut tabiin (setelah tabiin) semua itu dikarenakan setelah zaman mereka para ulama telah berpencar dan jumlahnya banyak, dan perselisihan semakin sering dan banyak terjadi, sehingga tak dapat dipastikan bahwa semua ulama telah bersepakat.

d. Qiyas merupakan sumber hukum Islam yang terakhir setelah Al-Quran, Al-Hadits dan Ijma' adalah Qiyas. Qiyas memiliki kegunaan dan fungsi untuk menjelaskan sesuatu yang tidak ada landasannya atau dalil nashnya dalam Al quran ataupun hadis dengan cara membandingkan sesuatu yang serupa dengan sesuatu yang hendak diketahui hukumnya tersebut. Artinya jika suatu nash telah menunjukkan hukum mengenai suatu kasus dalam agama Islam dan telah diketahui melalui salah satu metode untuk mengetahui permasalahan hukum tersebut, kemudian ada kasus lainnya yang sama dengan kasus yang ada nashnya itu dalam suatu hal itu juga, maka hukum kasus tersebut disamakan dengan hukum kasus yang ada nashnya.

Ada berbagai jenis dan macam Hukum Islam. Berbagai aspek kehidupan manusia, terdapat peraturan dan batasan yang harus ditaati dan tidak bias dilanggar. Bila berada dalam masyarakat maka hukum masyarakat harus dijunjung tinggi. Begitu pula dengan mempercayai agama Islam secara menyeluruh, yaitu agama yang memiliki mekanisme dan regulasi yang baik. Terdapat aturan/indikator yang pertama kali harus kita pahami adalah aturan yang berasal dari Allah SWT. Berbagai aturan yang berkaitan dengan Ilahi dalam segala bentuk 
hukum-hukum kehidupan manusia tertuang di dalam kitab suci Al-Qur'an, yang dilengkapi penjelasannya dalam hadits Nabi SAW. Ada lima hukum yang bias dikatakan merupakan adalah macam-macam hukum Islam: ${ }^{21}$

a. Hukum Wajib adalah sesuatu perbuatan yang jika dilakukan akan menimbulkan pahala dan jika ditinggalkan akan mendapat dosa. Seagai contoh dari perbuatan yang memiliki hukum wajib adalah shalat lima waktu, memakai hijab bagi perempuan, puasa, melaksanakan ibadah haji bagi yang mampu, menghormati orang non muslim dan banyak lagi. Perbuatan-perbuatan tersebut harus dan menjadi prioritas untuk di lakukan jika memilih untuk mempercayai agama Islam.

b. Hukum sunnah ialah sesuatu hukum yang menilai perbuatan yang dituntut agama, apabila dikerjakan tetapi tuntutannya tidak sampai ke tingkatan wajib atau sederhananya perbuatan yang jika dikerjakan akan mendapatkan pahala dan jika ditinggalkan tidak akan mendapatkan siksaan atau hukuman. Contoh dari perbuatan yang memiliki hukum sunnah ialah shalat yang dikerjakan sebelum/sesudah shalat fardhu, membaca shalawat Nabi, mengeluarkan sedekah dan sebagainya.

c. Hukum haram ialah sesuatu perbuatan yang jika dilakukan pasti akan mendapatkan dosa dan jika ditinggalkan akan mendapatkan pahala. Contoh perbuatan yang memiliki hukum haram adalah berbuat zina, minum alkohol, bermain judi, mencuri, korupsi dan banyak lagi. Hukum mengenai ketentuan haram sangat penting karena hukum haram yang menjadi hukum yang benar-benar memuat adnaya larangan dari ajaran agama.

d. Hukum makruh adalah suatu perbuatan yang dirasakan jika meninggalkannya itu lebih baik dari pada mengerjakannya. Contoh dari perbuatan makruh ini adalah makan bawang, merokok dan sebagainya. Ketentuan dari hukum ini tidak memberikan adanya hukuman dosa jika mengerjakannya tetapi hukum makruh menjelaskan bahwa jika seseorang melakukan suatu perbuatan maka orang tersebut tidak menadapatkan manfaat.

e. Hukum mubah adalah suatu tindakan yang dipersilakan dan dibolehkan oleh ketentuan agama antara mengerjakannya atau meninggalkannya. Contoh dari mubah adalah olahraga, menjalankan bisnis, sarapan dan sebagainya. Implikasi dan dampak dari hukum mubah tidak menunjukan adanya hukuman dan pahala jika melakukannya.

Berdasarkan permasalahan pada tulisan ini memperlihatkan bahwa ada klasifikasi dari hukum yang ada didalam hukum islam. Mengenai hal berkaitan dengan tulisan ini penulis menilai bahwa wasiat yang ingin diberlakukan dengan orang yang memiliki kepercayaan yang berbeda atau orang yang memiliki agama lain hukumnya adalah haram. Hukuman terseut haram dikarenakan pembagian harta wasiat tidak diperkenankan jika dibagikan kepada orang yang memiliki kepercayaan yang berbeda serta tidak bias dicampurkan mengenai ruang lingkup hukum islam dengan fenomena hukum yang terjadi pada saat ini mengenai wasiat yang melibatkan adanya orang asing dan memiliki perbedaan agama.

\section{Ijtihad Terhadap Wasiat Wajibah}

Wasiat wajibah merupakan sebuah tindakan yang dilakukan oleh pemegang kepentingan atau hakim sebagai aparat negara yang memberikan daya paksa atau memberi putusan wajib wasiat bagi orang yang telah meninggalkan dunia, yang diberikan kepada orang tertentu dalam keadaan tertentu pula. Dengan demikian dapat dilihat bahwa, wasiat wajibah memiliki definisi wasiat yang dilihatkan telah dilakukan oleh seseorang yang meninggal dunia, walaupun sebenarnya ia tidak meninggalkan wasiat tersebut. ${ }^{22}$ Berdasarkan definisi tersebut menjelaskan bahwa wasiat wajibah akan diimplementasikan melalui perantara hakim sebagai

\footnotetext{
${ }^{21}$ Barmawi Mukri, Op. Cit., 26.

${ }^{22}$ Zulfia Hanum, Alfi Syahr, "Wasiat Wajibah Sebagai Wujud Penyelesaian Perkara Waris Beda Agama Dalam Perkembangan Sosial Masyarakat", Jurnal Holistik 1, no. 2 (2016): 123-133, 123, DOI: 10.24235/holistik.v1i2.905
} 
penegak hukum yang berwenang dalam hal ini memberikan adanya ketentuan wasiat wajibah. Semua hal tersebut memperlihatkan bahwa untuk memberikan adanya kekuatan terhadap ketentuan wasiat wajibah harus dilakukan melalui putusan pengadilan.

Ijtihad berdasarkan rumusan ushuliyyin, yaitu "usaha dari mujtahid atau ahli fikih dengan mencurahkan segala kemampuan agar mendapatkan suatu hukum syara' dalam Islam". ${ }^{23}$ Kemudian Ibn Manzūr mendefinisikan istilah ijtihād sebagai "pencurahan segala kesanggupan, kekuatan dan kemampuan". ${ }^{24}$ Definisi ijtihad yang sesuai dengan era modern saat ini yaitu seseorang yang memiliki pengetahuan dan ilmu khusus dan kemudian dikerahkan secara maksimal untuk mengetahui ketentuan hukum syara' tentang suatu peristiwa baru atau dalam menerapkan kehendak syara' tersebut. ${ }^{25}$ Era modern seperti saat ini membuat ijtihad menjadi suatu kebutuhan dalam menyelesaikan berbagai permasalahan yang tidak terdapat penjelasan hukum yang pasti dari sumber utama hukum isalm yaitu al-Qur'an dan al-Hadits. ${ }^{26}$

Termasuk terkait wasiat wajibah, hanya ijtihad ulama tertentu yang diakui. Adapun pengertian wasiat menurut al-Ibyani merupakan suatu kondisi setelah matinya seseorang terkait kepemilikan suatu benda atau manfaat lain yang diberikan secara sukarela. ${ }^{27}$ Berdasarkan definisi Andi Syamsu Alam terkait wasiat wajibah yaitu harta warisan dari seseorang yang telah wafat diwasiatkan agar diberikan kepada kerabat dan ahli waris yang tidak memperoleh bagian disebabkan karena satu halangan yang syara'. ${ }^{28}$ Apabila kita melihat dasar yuridisnya telah diatur dalam Kompilasi Hukum Islam Nomor 1 Tahun 1991 yakni pada Pasal 194-Pasal 208 yang mengatur terkait wasiat biasa, ${ }^{29}$ lalu Pasal 209 mengatur tentang wasiat anak angkat dan orangtua angkat, atau dalam hukum Islam biasa disebut dengan wasiat wajibah. ${ }^{30}$

Kompilasi Hukum Islam menyebutkan bahwa wasiat wajibah adalah "suatu tindakan pembebanan oleh hakim atau lembaga yang mempunyai hak agar harta seseorang yang telah meninggal dunia tetapi tidak melakukan wasiat secara sukarela, agar diambil hak atau benda peninggalannya untuk diberikan kepada orang tertentu dalam keadaan tertentu pula". ${ }^{31}$ Pemberlakuan wasiat wajibah mempengaruhi peralihan nilai hak warisan dari ahli waris yang lain. Namun istilah ini tidak pernah dikenal dalam hukum Islam klasik. ${ }^{32}$ Kemudian terkait pembagian wasiat wajibah menurut KHI yaitu orang tua angkat mendapatkan wasiat wajibah dari harta anak angkatnya sebanyak-banyaknya $1 / 3$ atau tidak menerima wasiat. Sedangkan

\footnotetext{
${ }^{23}$ Hasani Ahmad Syamsuri, "IJTIHAD DAN SEKULARISASI: TELISIK ATAS TRADISI KEILMUAN ISLAM DAN BARAT”, $A L$ - 'ADALAH 10, no. 2 (2011): 221-236, 223, DOI: 10.24042/adalah.v10i2.264.

${ }^{24}$ Rokhmadi, "REKONSTRUKSI IJTIHĀDDALAM ILMU UȘULL AL-FIQH”, Al-Ahkam 22, no. 2 (2012): 161176, 164, DOI: 10.21580/ahkam.2012.22.2.9.

${ }^{25}$ Asep Arifin, "PEMIKIRAN QUTUB MUSHTHAFA SANU TENTANG METODOLOGI IJTIHAD”, AsySyariah 20, no. 1 (2018): 15-34, 16, DOI: 10.15575/as.v20i1.2981

${ }^{26}$ Abdur Rahem, "MENELAAH KEMBALI IJTIHAD DI ERA MODERN”, Islamuna 2, no. 2 (2015): 183-196, 183, DOI: 10.19105/islamuna.v2i2.661.

27 Yasir Fauzi, "PEMBAGIAN HARTA DENGAN WASIAT WAJIBAH DAN HIBAH DALAM HUKUM ISLAM", Asas: Jurnal Hukum dan Ekonomi Islam 9, no. 1 (2017): 103-110, 104, DOI: 10.24042/asas.v9i1.1218. 28 Alip Pamungkas Raharjo, Elok Fauzia Dwi Putri, "ANALISIS PEMBERIAN WASIAT WAJIBAH TERHADAP AHLI WARIS BEDA AGAMA PASCA PUTUSAN MAHKAMAH AGUNG NOMOR 331 K/AG/2018," Jurnal Suara Hukum 1, no. 2 (2019): 172-185, 174, DOI: 10.26740/1.JSH.2019.1.2.4865.

${ }^{29}$ Destri Budi Nugraheni, Haniah Ilhami, and Yulkarnain Harahab, Op.Cit., 312

30 A. G. Ramadhani, N. Ngadino, and I. irawati, "PELAKSANAAN WASIAT WAJIBAH MENURUT KOMPILASI HUKUM ISLAM DALAM PRAKTEK PENGADILAN AGAMA SAMBAS," NOTARIUS 13, no. 1 (2019): 37-46, 38, DOI: 10.14710/nts.v13i1.29160.

${ }^{31}$ Misno, "WASIAT WAJIBAH UNTUK ANAK ANGKAT DALAM KHI DAN FIKIH", ADLIYA: Jurnal Hukum dan Kemanusiaan 11, no. 1 (2017): 99-118, 101, DOI: 10.15575/adliya.v11i1.4854.

32 Ria Ramdhani, "PENGATURAN WASIAT WAJIBAH TERHADAP ANAK ANGKAT MENURUT HUKUM ISLAM", Lex et Societatis 3, no. 1 (2015): 55-63, 60.
} 
bagi anak angkat dari harta warisan orang tua angkatnya mendapatkan sebanyak-banyaknya $1 / 3$ atau tidak menerima wasiat.

Dalam menyelesaikan perkara wasiat wajibah, hakim memiliki keluasan wewenang untuk melakukan ijtihad. Secara umum, keluasan hakim dalam melakukan Ijtihad harus berdasarkan pada pada asas keseimbangan dan asas keadilan. Sehingga putusan yang ditetapkan oleh hakim terkait wasiat wajibah dapat dijadikan sumber hukum yang membawa kemaslahatan terhadap masyarakat. ${ }^{33}$ Namun dalam perkembangan dikehidupan masyarakat saat ini terdapat penggunaan dan besarnya pembagian wasiat wajibah di Indonesia. Perkembangan wasiat wajibah ini secara nyata terlihat dalam Putusan Mahkamah Agung sebagai Pengadilan Negara Tertinggi.

Terdapat perbandingan ketentuan mengenai adnaya wasiat wajibah di negara lain. Pertama kali dikenalkannya mengenai adanya wasiat wajibah ini berawal dari Mesir. Ulama Mesir memperlihatkan bahwa 'cucu' yang terhalang oleh anak laki-laki dapat dicarikan jalan keluarnya dan solusi untuk tetap mendapat bagian integral dengan jalan wasiat wajibah. Wasiat wajibah di Mesir ini diatur dalam UU Wasiat Mesir No. 71 tahun 1946, pasal 76-79. Ketentuan mengenai wasiat wajibah ini diperuntukan untuk cucu atau cucu-cucu yang ayah/ibunya meninggalkan dunia, lebih dahulu atau bersamaan waktunya dengan pewaris (kakek/nenek mereka) dengan ketentuan: ${ }^{34}$

a. Kalau dari garis keturunan laki-laki maka bisa berlaku seterusnya sampai ke bawah tetapi kalau dari garis keturunan anak perempuan hanya terbatas sampai pada anak atau anakanak dari anak perempuan dari pewaris saja.

b. Pewaris di masa hidupnya belum pernah melakukan adanya pemberian harta kepada yang berhak menerima wasiat wajibah tersebut seukuran hak wasiat wajibahnya.

c. Besarnya jumlah wasiat wajibah hanyalah sepertiga harta, entah yang berhak menerima wasiat wajibah itu banyak atau sedikit, campuran antara laki-laki atau perempuan ataupun tidak. Kalau yang berhak menerima wasiat wajibah tersebut campuran antara orang yang memiliki jenis kelamin laki-laki dan orang dengan jenis kelamin perempuan maka bagian dari wasiat mereka mereka adalah dua banding satu (2:1)

d. Wasiat wajibah dilaksanakan dari wasiat biasa. Kalau pewaris telah membentuk wasiat kepada mereka yang berhak menerima wasiat wajibah tetapi kurang jumlahnya dari sepertiga maka dicukupkanlah sampai jumlah sepertiga, tetapi bila telah melebihi dari sepertiga maka kelebihan itu dianggap wasiat biasa. Kalau yang berhak menerima wasiat wajibah tersebut lebih dari seorang, maka ada yang diberi wasiat biasa dan ada yang tidak maka yang belum diberi tersebut berhak mendapatkan hak bagian wasiat wajibahnya. Kalau pewaris ada membuat surat wasiat bisa dan ada pula meninggalkan mereka yang berhak menerima wasiat wajibah maka wasiat wajibah diberikan dulu dalam batas sepertiga, kemudian baru diambilkan untuk wasiat biasa dalam batas sepertiga pula (sesudah diambil untuk wasiat wajibah).

Berbagai ahli dalam bidang agama salah satunya adalah ulama berusaha memberikan penjelasan mengenai hal tersebut. Sebagian ulama dalam mengartikan dan memaknai definisi dari ayat tersebut berpendapat dan memberikan masukan bahwa wasiat (kepada ibu, bapak dan kerabat) yang asalnya wajib sampai sekarang pun kewajiban tersebut masih tetap dilaksanakan terhadap hal tersebut. Sehingga, pemberian wasiat wajibah kepada walidain dan aqrabin yang diberikan bagian (penerimaan) dapat diterapkan dan dilaksanakan. Wasiat

\footnotetext{
${ }^{33}$ S. (Syafi'i) Syafi'i, "WASIAT WAJIBAH DALAM KEWARISAN ISLAM DI INDONESIA," Misykat 2, no. 2 (2017): 119-130, 129, DOI: 10.33511/MISYKAT.V2I2.7.

34 Anshoruddin, Lembaga Wasiat Wajibah dalam Kompilasi Hukum Islam dalam Perspektif Sosiologi (Pontianak: Pontianak, 2015), 11.
} 
wajibah ini harus memenuhi agar memenuhi unsur. Terdapat 2 (dua) persyarat yang harus dipenuhi yaitu: ${ }^{35}$

Pertama: yang wajib menerima wasiat, bukan waris. Kalau dia berhak menerima pusaka walaupun sedikit, tidaklah wajib dibuat wasiat untuknya.

Berdasarkan syarat yang ditentukan dalam poin pertama, menjelaskan bahwa ketentuan yang mewajibkan adanya pemberian dari wasiat wajibah adalah orang yang menerima harta pusaka walaupun harta pusaka yang diterima tidak berjumlah banyak.

Kedua: orang yang meninggal, baik kakek maupun nenek belum memberikan kepada anak yang wajib dibuat wasiat, jumlah yang diwasiatkan dengan jalan yang lain, seperti hibah umpamanya.

Penjelasan mengenai poin kedua menjabarkan bahwa orang yang meninggal dalam hal ini kakek, nenek yang tidak mempunyai anak dan melahirkan anak memiliki hak atas wasiat tersebut.

Adapun adanya hukum wasiat yang wajib atau wasiat wajibah sebagaimana telah jabarkan di atas adalah karena adanya penjelasan mengenai ketentuan ayat 180 surat al-Baqarah tersebut. Sebagian ulama memiliki pandangan bahwa ketentuan wasiat wajib (wasiat wajibah) kepada seseorang dengan memiliki alasan tersebut, ayat mawaris (al-Quran surat an-Nisa': 11) tidak me-nasakh ayat wasiat, melainkan hanya mengkhususkan hukum bagi ahli waris yang mendapat bagian warisan. Untuk adanya orang tua dan kerabat yang tidak mendapat warisan karena terkendala oleh ketentuan ketentuan, tetap mendapat bagian melalui jalan wasiat wajibah. Misalnya ditujukan pada orang tua dan kerabat yang non-muslim. ${ }^{36}$

\section{Analisis Yuridis Ijtihad Atas Wasiat Wajibah Terhadap Ahli Waris Beda Agama Di Indonesia}

Penemuan hukum oleh hakim atas wasiat wajibah terhadap kasus pembagian harta waris beda agama merupakan hal tidak aneh pada zaman sekarang ini. Hal ini menandakan bahwa seorang hakim diberikan kebebasan dalam memutus suatu perkara. Pengambilan suatu keputusan sangat diperlukan oleh hakim atas segala sengketa yang diperiksa dan diadilinya. Selanjutnya lebih merujuk kedalam wasiat wajibah. Dalam praktiknya sering kita menemukan beberapa putusan Mahkmah Agung memberikan harta waris kepada ahli waris beda agama. Salah satunya putusan nomor 331K/AG/2018. Setelah melakukan penelitian dengan seksama, adapun yang menjadi dasar pertimbangan seorang hakim adalah rasa kemanusiaan. Sebenarnya kita tahu bahwa ini sangat bertentangan dengan Al-Qur'an dan Al-Hadits sebagai sumber utama hukum islam. Dasar hukum berbeda agama sebagai penghalang saling mewaris adalah hadits riwayat Al-Bukhari dan Muslim.

"Dari Ibnu Abbas R.A bahwa Rasullah SAW bersabda: orang Islam tidak berhak mewarisi harta orang kafir dan orang kafir tidak berhak mewarisi harta orang Islam". (HR-AlBukhari)."

Majelis Ulama Indonesia merupakan lembaga yang memiliki tugas dalam mengeluarkan penjelasan atau fatwa terkait permasalahan dan kebutuhan umat islam. ${ }^{37}$ Terkait wasiat wajibah terhadap ahli waris beda agama, MUI juga mengeluarkan fatwa yakni pada 28 Juli 2005. Fatwa MUI terkait ahli waris beda agama atau non-muslim ditetapkan dalam fatwa Nomor: 5/MUNASVII/MUI/9/2005, yaitu:

\footnotetext{
35 Barmawi Mukri, Op. Cit., 28.

${ }^{36}$ Habiburrahman, Rekonstruksi Hukum Kewarisan Islam di Indonesia (Jakarta : Kencana Prenada Media Group, 2011), 246-265.

37 Jamal Makmur, "PERAN FATWA MUI DALAM BERBANGSA DAN BERNEGARA", Wahana Akademika: Jurnal Studi Islam dan Sosial 5, no. 2 (2018): 41-52, 45, DOI: 10.21580/wa.v5i2.3226
} 
"Hukum waris Islam tidak memberikan hak saling mewarisi antara orang-orang yang berbeda agama (antara muslim dengan non-muslim); Pemberian harta orang berbeda agama hanya dapat dilakukan dalam bentuk hibah, wasiat dan hadiah".

Dengan demikan perkembangan wasiat wajibah saat ini tidak hanya diperuntukkan untuk anak angkat dan orangtua angkat saja namun sudah dipergunakan untuk ahli waris beda agama. Penempatan hukum wasiat wajibah oleh hakim ini sebenarnya sangat relevan dengan melihat beragam suku, agama di Indonesia. Hal ini diharapkan terciptanya keadilan social dan demi kelancaran kelangsungan hidup ahli waris yang berbeda agama. Dengan ini dengan adanya putusan Mahkamah Agung merealisasikan putusannya dengan penerapan wasiat wajibah dengan berlandaskan keadilan dan kemanusiaan.

Terdapat beberapa yurisprudensi yang bisa menjadi rujukan dalam menyelesaikan permasalahan mengenai wasiat tersebut. Dasar hukum dalam yurisprudensi tersebut menjelaskan bahwa wasiat wajibah bagi ahli waris beda agama yang tercantum didalam Putusan Mahkamah Agung Nomor 368.K/AG/1995, didalam putusan tersebut memperlihatkan beberapa alasan hakim memberikan bagian wasiat wajibah terhadap ahli waris beda agama. Alasan-alasan tersebut dipaparkan sebagai berikut:

a. Adanya faktor sejarah, larangan memberikan warisan pada ahli waris yang tidak beragama Islam. Alasan pertama, yaitu regulasi yang menghambat adnaya pemberian warisan kepada ahli waris non-muslim, secara sejarah ditetapkan pada waktu peperangan antara kaum islam dengan orang tidak beragama islam di masa lalu. Berguna untuk memberikan perlindungan akidah dan harta yang dimiliki orang muslim dari penguasaan ahli waris non-muslim yang berpotensi untuk digunakan sebagai sarana untuk melawan umat Islam sendiri, maka larangan tersebut diimplementasikan. Melihat kondisi saat ini dimana tidak ada lagi peperangan antara orang muslim dan non-muslim, maka ketentuan yang menghambat tersebut dinilai tidak dipergunakan.

b. Penggunaan metode interpretasi aspek sosiologis dalam mencari adanya sebuah penemuan hukum. Alasan kedua berhubungan dengan kewajiban hakim untuk menemukan hukum atas setiap perkara yang ada dihadapannya dan ia memiliki kewajiban untuk melakukan hal tersebut. Kewajiban ini berasal dari salah satu asas dalam hukum formil, bahwa hakim tidak boleh menolak adanya perkara dengan alasan tidak terdapat sumber hukumnya, karena hakim sebagai wasit sudah memiliki kewenangan hukum untuk melakukan penemuan hukum. Penetapan wasiat wajibah bagi ahli waris yang terhalang untuk menerima warisan karena tidak beragama Islam merupakan terobosan hasil dari penemuan hukum yang dilaksanakan oleh pribadi hakim dengan metode interpretasi sosiologis dan keyakinan nuraninya.

c. Penggunaan cara argumentum per analogium dalam melakukan penemuan hukum. Alasan ini merupakan alasan yang ketiga, penggunaan cara argumentum per analogium dalam menetapkan wasiat wajibah dilakukan sebagai implementasi dari asas ius curia novit oleh seorang penegak hukum dalam hal ini seorang hakim di lingkungan Peradilan Agama. Berkaitan dengan hakim melakukan penemuan hukum terhadap pemberian wasiat wajibah terhadap ahli waris yang beda agama, hakim menggunakan metode argumentum per analogian dengan sarana menemukan ketentuan regulasi atau hukum lain yang serupa, memiliki kesamaan, serta adanya tuntutan dalam masyarakat untuk mendapatkan penilaian yang sama. Ketentuan yang serupa untuk menyelesaikan adanya kekosongan dalam hal ini adalah menggunakan ketentuan wasiat wajibah yang ada dalam KHI khusus untuk anak angkat dan atau orang tua angkat. Terhadap kedua fenomena hukum tersebut, terdapat kesamaan antara keduanya, yaitu keduanya terjadi pada orangorang yang secara legalistik tidak mendapatkan bagian harta warisan, bahkan ketika mereka mempunyai hubungan kekeluargaan dengan pewaris baik sebagai anak kandung, maupun anak angkat dari kedua orang tuanya. Adanya persamaan dari ketentuan tersebut, 
memberikan implikasi adanya regulasi yang berlaku pada satu peristiwa diberlakukan pula pada peristiwa lain, sehingga ketentuan wasiat wajibah bagi anak angkat diberlakukan pula pada anak atau ahli waris yang beda agama.

d. Keberadaan dari hukum kewarisan Islam di antara sistem hukum kewarisan lainnya. Landasan keempat yang menjadi alasan tersebut digunakan oleh hakim dalam menetapkan pemberian wasiat wajibah bagi ahli waris beda agama adalah keberadaan dari hukum waris Islam dalam sistem hukum nasional secara menyeluruh. Berdasarkan fakta yang ada di lapangan, hukum waris Islam di Indonesia berkembang dan selalu hidup di setiap sendi-sendi masyarakat, berkembang dan berdampingan dengan hukum waris lain, yaitu hukum waris adat dan hukum waris barat. Ketiga ketentuan dan jenis hukum tersebut digunakan sebagai pilihan hukum bagi rakyat secara meyeluruh dari sabang hingga merauke. Penemuan hukum yang memberikan wasiat wajibah bagi ahli waris beda agama merupakan upaya mengimplementasikan adanya ketentuan hukum Islam di tengah-tengah masyarakat Indonesia yang majemuk dan berisikan orang dari berbagai latarbelakang, baik di bidang sosial, budaya, hukum, maupun agama.

Empat alasan tersebut memberikan pandangan yang menguatkan adanya analisis dari permasalahan saat ini. Kedudukan yurisprudensi sangat membantu adanya perkembangan hukum di masyarakat. Sistem hukum yang ada perlu disesuaikan dengan pengalamanpengalaman terdahulu. Tujuannya adalah agar para penegak hukum semakin bisa menilai dan memperkaya referensi dalam hal hakim memutuskan sebuah perkara secara konkrit dan jelas.

\section{Kesimpulan}

Berdasarkan pemaparan yang penulis jelaskan, maka dapat ditarik kesimpulan bahwa hakim agung dalam memutus perkara waris beda agama ini lebih mempertimbangkan aspek keadilan sosial dan kemaslahatannya. Walaupun hal ini sebenarnya bertentangan dengan sumber Hukum Islam baik dalam Al-Qur'an maupun Hadits. Ketentuan wajib wajibah merupakan sesuatu hal yang tidak diatur di dalam sistem hukum di Indonesia. Perkembangan wasiat wajibah saat ini tidak hanya ditujukan untuk anak angkat dan orangtua angkat saja namun sudah dipergunakan untuk ahli waris beda agama. Penempatan hukum wasiat wajibah oleh hakim ini sebenarnya sangat berhubungan dengan melihat beragam suku dan etnis serta agama di Indonesia. Cita-cita agar terwujudnya keadilan social dan demi kelancaran kelangsungan hidup ahli waris yang berbeda agama. Melalui adanya putusan Mahkamah Agung yang telah merealisasikan putusannya dengan penerapan wasiat wajibah dengan berlandaskan keadilan dan kemanusiaan.

\section{A. Jurnal}

\section{DAFTAR PUSTAKA}

Arief, Abd. Salam. "IJTIHAD DAN DINAMIKA HUKUM ISLAM," IN RIGHT: Jurnal Agama dan Hak Azazi Manusia 7, no. 1, 2017: 1-14.

Arifin, Asep. "PEMIKIRAN QUTUB MUSHTHAFA SANU TENTANG METODOLOGI IJTIHAD”, Asy-Syariah 20, no. 1, 2018: 15-34, DOI: 10.15575/as.v20i1.2981.

Basri. "PERKEMBANGAN PERADILAN AGAMA PASCA LAHIRNYA UU NOMOR 7 TAHUN 1989 HINGGA SAAT INI (KEWENANGAN, PEMBINAAN, PENGAWASAN DAN DASAR HUKUM)," TAHKIM 13, no. 2, 2018: 31-46, DOI: 10.33477/THK.V13I2.366.

Damanik, Agusman. "URGENSI STUDI HADIS DI UIN SUMATERA UTARA," SHAHIH (Jurnal Kewahyuan Islam) 1, no. 1, 2018: 83-94, DOI: 10.30821/SHAHIH.V1I1.1886.

Daud, Mohammad. "KEDUDUKAN HUKUM ISLAM DALAM SISTEM HUKUM INDONESIA," Jurnal Hukum \& Pembangunan 12, no. 2, 1982: 267-287, DOI: 10.21143/jhp.vol12.no2.898. 
Daulay, Muhammad Roihan. "STUDI PENDEKATAN ALQURAN," Thariqah Ilmiah 1, no. 01, 2014: 31-45.

Fauzi, Yasir. "PEMBAGIAN HARTA DENGAN WASIAT WAJIBAH DAN HIBAH DALAM HUKUM ISLAM", Asas: Jurnal Hukum dan Ekonomi Islam 9, no. 1, 2017: 103-110, DOI: 10.24042/asas.v9i1.1218.

Hermawan, Dadang., Sumardjo. "KOMPILASI HUKUM ISLAM SEBAGAI HUKUM MATERIIL PADA PERADILAN AGAMA”, Yudisia 6, no. 1, 2015: 24-46.

Iryani, Eva. "HUKUM ISLAM, DEMOKRASI DAN HAK ASASI MANUSIA," Jurnal Ilmiah Universitas Batanghari Jambi 17, no. 2, 2017: 24-31, DOI: 10.33087/JIUBJ.V17I2.357.

Kholid, Muhamad. "KEWENANGAN PENGADILAN NEGERI DAN LEMBAGA ARBITRASE DALAM PENYELESAIAN SENGKETA BISNIS," ADLIYA: Jurnal Hukum Dan Kemanusiaan 9, no. 1, 2015: 168-184, DOI: 10.15575/ADLIYA.V9I1.6162.

Mahdewi, Risa., Banjarani, Desia Rakhma. "FOOD SAFETY OF GENETICALLY MODIFIED ORGANISM ACCORDING TO INTERNATIONAL LAW AND ITS IMPLEMENTATION IN INDONESIA," Lampung Journal of International Law 2, no. 1, 2020: 35-46, DOI: 10.25041/lajil.v2i1.2031.

Makmur, Jamal. "PERAN FATWA MUI DALAM BERBANGSA DAN BERNEGARA", Wahana Akademika: Jurnal Studi Islam dan Sosial 5, no. 2, 2018: 41-52, DOI: 10.21580/wa.v5i2.3226

Misno. "WASIAT WAJIBAH UNTUK ANAK ANGKAT DALAM KHI DAN FIKIH", ADLIYA: Jurnal Hukum dan Kemanusiaan 11, no. 1, 2017: 99-118, DOI: 10.15575/adliya.v11i1.4854.

Mukri, Barmawi. "KEDUDUKAN DAN PERANAN KOMPILASI HUKUM ISLAM DALAM SISTEM HUKUM NASION AL," Jurnal Hukum IUS QUIA IUSTUM 8, no. 17, 2016: 22-29.

Nugraheni, Destri Budi, et.al. "PENGATURAN DAN IMPLEMENTASI WASIAT WAJIBAH DI INDONESIA," Mimbar Hukum 22, no. 2, 2010: 311-329, DOI: 10.22146/jmh.16229.

Nuzula, Nikmatun. "PEMBAGIAN HARTA BERSAMA AKIBAT PERCERAIAN DI PENGADILAN AGAMA KEDIRI," Mahakim: Journal of Islamic Family Law 1, no. 1, 2017: 27-37, DOI: 10.30762/mh.v1i1.1009.

Raharjo, Alip Pamungkas., Putri, Elok Fauzia Dwi. "ANALISIS PEMBERIAN WASIAT WAJIBAH TERHADAP AHLI WARIS BEDA AGAMA PASCA PUTUSAN MAHKAMAH AGUNG NOMOR 331 K/AG/2018," Jurnal Suara Hukum 1, no. 2, 2019: 172-185, DOI: 10.26740/1.JSH.2019.1.2.4865.

Rahem, Abdur. "MENELAAH KEMBALI IJTIHAD DI ERA MODERN", Islamuna 2, no. 2, 2015: 183-196, DOI: 10.19105/islamuna.v2i2.661.

Ramadhani, A. G., et.al. "PELAKSANAAN WASIAT WAJIBAH MENURUT KOMPILASI HUKUM ISLAM DALAM PRAKTEK PENGADILAN AGAMA SAMBAS," NOTARIUS 13, no. 1, 2019: 37-46, DOI: 10.14710/nts.v13i1.29160.

Ramdhani, Ria. "PENGATURAN WASIAT WAJIBAH TERHADAP ANAK ANGKAT MENURUT HUKUM ISLAM”, Lex et Societatis 3, no. 1, 2015: 55-63.

Rokhmadi. "REKONSTRUKSI IJTIHĀDDALAM ILMU USTUL AL-FIQH', Al-Ahkam 22, no. 2, 2012: 161-176, DOI: 10.21580/ahkam.2012.22.2.9.

Samniah, Ruwainta., Khisni, Akhmad. "KEDUDUKAN DAN KONTRIBUSI HUKUM ISLAM TERHADAP HUKUM NASIONAL DALAM BIDANG MU'AMALAT," Jurnal Hukum Khaira Ummah 12, no. 3, 2017: 671-676. 
Sumarni. "KEDUDUKAN HUKUM ISLAM DALAM NEGARA REPUBLIK

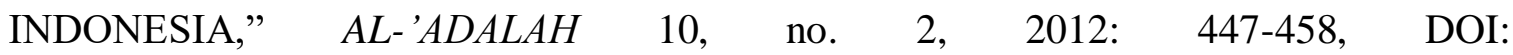
10.24042/ADALAH.V10I2.298.

Syafi'i. "WASIAT WAJIBAH DALAM KEWARISAN ISLAM DI INDONESIA," Misykat 2, no. 2, 2017: 119-130, DOI: 10.33511/MISYKAT.V2I2.7.

Syamsuri, Hasani Ahmad. "IJTIHAD DAN SEKULARISASI: TELISIK ATAS TRADISI KEILMUAN ISLAM DAN BARAT", $A L$ - 'ADALAH 10, no. 2, 2011: 221-236, DOI: 10.24042/adalah.v10i2.264.

Zubaidi, Zaiyad., Yanis, Muhammad. "IMPLEMENTASI WASIAT BERUPA 'HONORARIUM' MENURUT PANDANGAN WAHBAH ZUHAILI," Media Syari'ah 20, no. 2, 2020: 182-200, DOI: 10.22373/jms.v20i2.6514.

Zulfia Hanum, Alfi Syahr, "Wasiat Wajibah Sebagai Wujud Penyelesaian Perkara Waris Beda Agama Dalam Perkembangan Sosial Masyarakat", Jurnal Holistik 1, no.2, (2016), 123133. DOI: $10.24235 /$ holistik.v1i2.905.

\section{B. Buku}

Amran, Suadi., Chandra, Mardi. Politik Hukum Perspektif Hukum Perdata dan Pidana Islam serta Ekonomi Syariah. Jakarta: Kencana, 2016.

Anshoruddin, Lembaga Wasiat Wajibah dalam Kompilasi Hukum Islam dalam Perspektif Sosiologi, Pontianak: Pontianak, 2015.

Habiburrahman, Rekonstruksi Hukum Kewarisan Islam di Indonesia, Jakarta: Kencana Prenada Media Group, 2011.

\section{Internet}

Putu Yasmin, 6 Agama di Indonesia Kitab Suci dan Hari Besarnya, https://news.detik.com/berita/d-4904472/6-agama-di-indonesia-kitab-suci-dan-haribesarnya diakses pada 01 October 2020. 
